\title{
Plantago Ovata Efficiency in Elimination of Water Turbidity
}

\author{
Gholamreza Nabi BIDHENDI $^{1}$, Toktam SHAHRIARI ${ }^{1}$, Sh SHAHRIARI ${ }^{2}$ \\ ${ }^{1}$ Faculty of Environment, University of Tehran, Tehran, Iran \\ ${ }^{2}$ Department of Architecture, University of Payamenoor, Tehran, Iran \\ E-mail:ghhendi@ut.ac.ir,Shahriari1353@yahoo.com \\ Received January 23, 2009; revised May 19, 2009; accepted May 21, 2009
}

\begin{abstract}
Coagulation and flocculation are the most important processes in water treatment plants. Nowadays, in Iran, coagulants which have the most usage in water treatment are Aluminum Sulphate (Alum) and Ferric Chloride. Using synthetic coagulants are not economical and useful for health in developing countries. The aim of this research is to survey and compare the Ferric Chloride coagulant function and this coagulant accompany with Plantago ovata coagulant aid under variable $\mathrm{pH}$ for eliminating of water turbidity.

This study was performed in lab scale for water containing artificial turbidity of clay. The experiments were done in three turbidity ranges 100, 50, 20 NTU and two ranges of $\mathrm{pH} 7$ and 8. The amount of Ferric Chloride in all experiments were $10 \mathrm{ppm}$ and P.ovata extarct in optimum concentration for turbidity of 100 , 50, $20 \mathrm{NTU}$ was $0.2 \mathrm{ppm}, 0.1 \mathrm{ppm}$ and $0.04 \mathrm{ppm}$ respectively. The optimum $\mathrm{pH}$ was 7 . Using P.ovata coagulant aid in turbidity $100,50,20$ NTU can eliminate $94.1,94.5,88.15$ percent of above turbidities, while using Ferric Chloride coagulant alone in optimum $\mathrm{pH}$ can eliminate 90.3, 85.16, 80.2 percent of the turbidities mentioned above. Results show that P.ovata extract is less efficient in high turbidities when used as a coagulant aid. Plantago ovata, as a coagulant aid, showed positive influence on turbidity removal from water. In addition, optimized $\mathrm{pH}$ showed important role in reducing turbidity.
\end{abstract}

Keywords: Water Treatment, Coagulation and Flocculation, Jar Test, Turbidity, Plantago Ovata, Ferric Chloride

\section{Introduction}

About million peoples of the world suffering lack of sanitary drinking water. Every year, more than 6 million peoples (about 2 million children) are dieing, because of polluted drinking water, and developing countries expend a lot for importing chemical materials like Poly Aluminum Chloride and Alum [1]. Surface water has got different kinds of suspended materials which cause turbidity and color [2,3]. Coagulation and flocculation are physic and chemical processes in which small particles causing turbidity and color change into giant particles and finally their elimination will be performed by different physical methods such as sedimentation, and filtration [4). Coagulants were used many years ago and Egyptians used Alum 2000 year B.C. [5]. Usually, metallic salts such as Alum, Ferric Sulphate, Ferro Sulphate,
Ferric Chloride, Anion, cation and non ionic organic polymers are among coagulant materials [6]. Several researches have been done on the function of coagulant materials and appointing the best $\mathrm{pH}$ [7]. Nowadays by using usual salts of Iron and aluminum a new group of coagulants named inorganic polymers have been produced and used in many countries of the world especially China, Japan, Russia and Western European countries $[8,9]$. Among them Poly Aluminium Chloride ( $\mathrm{PACl})$ the most usual is vastly used [8]. Inorganic metallic salts make unstable the particles by pressing double electrical layers around colloid particles, while polymers perform instability functions by absorption in colloid particle surface and making bridge among polymer particles [10]. Using metal coagulants and $\mathrm{Al}$ and $\mathrm{Fe}$ (III) salts started in U.S. since 1880. Application of active silica (a kind of anionic polymer) as coagulant aid was presented in 1930. 
Then synthetic poly electrolytes entered the market and presented interesting abilities in elimination turbidity since 1960 [11]. Many of the developing countries are using natural poly electrolytes like Chitosan [12-14].

Historical records of using different parts of plants such as, root, stem and seed for making clear water is related to Sanskrit book which says more than 4000 years ago Indians used seeds of Nirmali tree for making clear water from turbid water of the rivers. In many countries of the world using artificial polymers as coagulant and coagulant aid have been forbidden because of bad effects on human health $[12,13,15,16]$. This research studies the application of P.ovata as a coagulant aid. In addition, because of lack of comprehensive studies concerning elimination of turbidity with P.ovata as a coagulant aid and also in accompany with coagulant Ferric Chloride.

Plantago ovata is a native Iranian plant. It is a small, one year old plant without or with very short stem covered with soft fiber, from Plantginaceae family and its height is 7 to 30 centimeters [17-21]. P.ovata seeds contain Mosilaj, protein, fixed oil, cellulose and starch [17]. P.ovata seeds contain 30 percent [22] or 10 percent [23] musilaj which produces D-galacturonic acid under hydrolyze $[17,22,24]$.

\section{Materials and Methods}

In this study, while preparing artificial water turbidity, the effect of adding coagulant aid in optimum $\mathrm{pH}$ to improve turbidity elimination was studied, and necessary comparisons were made practically. It is not possible to store enough water containing natural turbidity in the laboratory because of instability. Therefore, in this study, water containing three turbidities: high turbidity of 100 NTU, medium 50 NTU and low 20 NTU were added to the tap water by clay which was sieved with mesh 60 for making artificial turbidity. Ferric Chloride $\left(\mathrm{FeCl}_{3}, 6 \mathrm{H}_{2} \mathrm{O}\right)$ made in Merck $\mathrm{KGaA}$ as coagulant and extract of P.ovata as coagulant aid were used. Sulphuric acid (1N) was used in this study to regulate $\mathrm{pH}$ value. The experiments were performed in the water and waste water lab of the faculty of environment, University of Tehran.

Experimental conditions of all experiments are as follows:

1) Experiments were performed in $25 \pm 2{ }^{\circ} \mathrm{C}$ because temperature is one of the most effective parameters on density, viscosity and amount of coagulants in keeping conditions.

2) The volume of applied water was $500 \mathrm{cc}$ for all three applied turbidities.

3) Chemical oxygen demand (COD) was determined by Spectrophotometer DR/2000HACH.

4) TOC of samples for examining TOC before and after using coagulant aid P.ovata was measured by Spe- ctrophotometer HACH- LANGE DR/5000 uv/vis.

5) $\mathrm{pH}$ of the samples was measured by digital $\mathrm{pH}$ meter Metrohm Model 691.

6) Turbidity was determined by turbidity meter gage HANNA.

7) Digital scale METTLER AE200 was used for weighing.

All the experiments were performed by using jar experiment method. Jar unit PHIPPS \& BIRD STIRRER MODEL 7790-402 was used.

\subsection{Preparation of P.ovata Extract}

At first, the seeds of plants were soaked in water for 24 hours. The obtained gelatine was filtered and dried at $105 \pm 5^{\circ} \mathrm{C}$ in oven. The obtained powder was used for the experiments. Plants contain mosilaj, protein, cellulose and starch $[17,22,24]$.

\subsection{Method of Experiment}

In this study, at first 5 samples of $500 \mathrm{ml}$ water which its $\mathrm{pH}$ and turbidity has already been measured and contained the turbidity of 100,50 or $20 \mathrm{NTU}$, was poured in special jar vessels, one time with known amount of coagulant Ferric Chloride and another time with coagulant Ferric Chloride with in accompany coagulant aid P.ovata.

The samples were shaken for one minute with $100 \mathrm{cy}$ cles per minute, then 25 minutes with 30 cycles per minute to make Floc. During this time, formation of Flocs were observed, then Flocs were allowed to settle for 30 minutes and after that jars were sampled for analyzing and measuring turbidity and $\mathrm{pH}$. The residual turbidity was compared with initial turbidity. In addition, $\mathrm{pH}$ variations were examined. This method was repeated for four times, Sulphuric acid (1N) was used to study the influence of $\mathrm{pH}$ on efficiency of coagulant aid P.ovata. Then $\mathrm{pH}$ variation as well as final turbidity of the samples was compared with the initial values.

\section{Discussion and Conclusions}

In this research, the role of P.ovata in elimination of water turbidity was studied, using coagulation and flocculation processes. P.ovata coagulant aid was used to reduce Ferric chloride consumption and optimum value and optimum $\mathrm{pH}$ were determined. One of the most important parameters was the amount of produced sludge which examined in each stage. Obtained results concerning use of Ferric Chloride alone and with coagulant aid in variable $\mathrm{pH}$, were shown in Figures 1 to 10.

Figures 1, 3 and 5 show results for $\mathrm{pH}, 7$ and for consumption Ferric Chloride alone and with coagulant aid P.ovata. Figures 2, 4 and 6 for $\mathrm{pH}, 8$ is produced. 


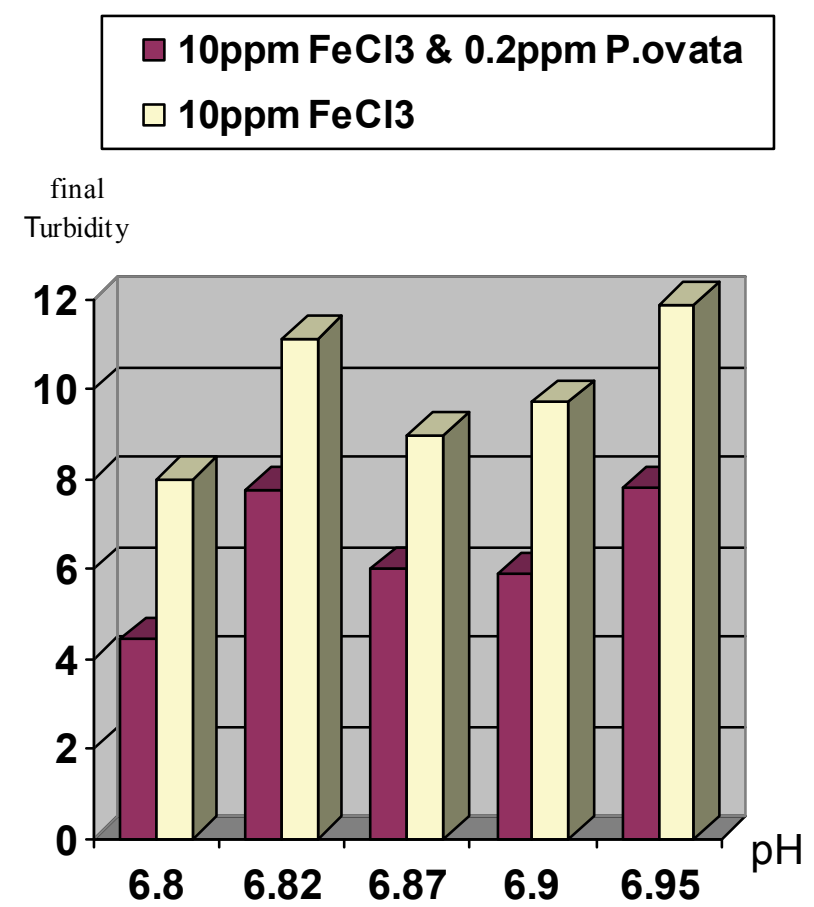

Figure 1. Comparison of final turbidities at initial pH 7 and 100(NTU) turbidity in two stages. Stage1: Ferric Chloride coagulant and Stage2: Ferric Chloride coagulant in accompany with P.ovata coagulant aid.

sludge weight $=0.039 \mathrm{gr} \quad \square$ sludge weight $=0.042 \mathrm{gr}$

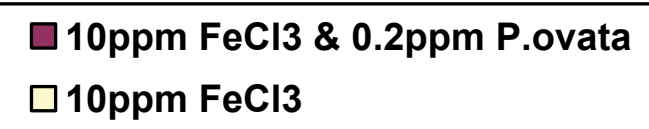

final

Turbidity

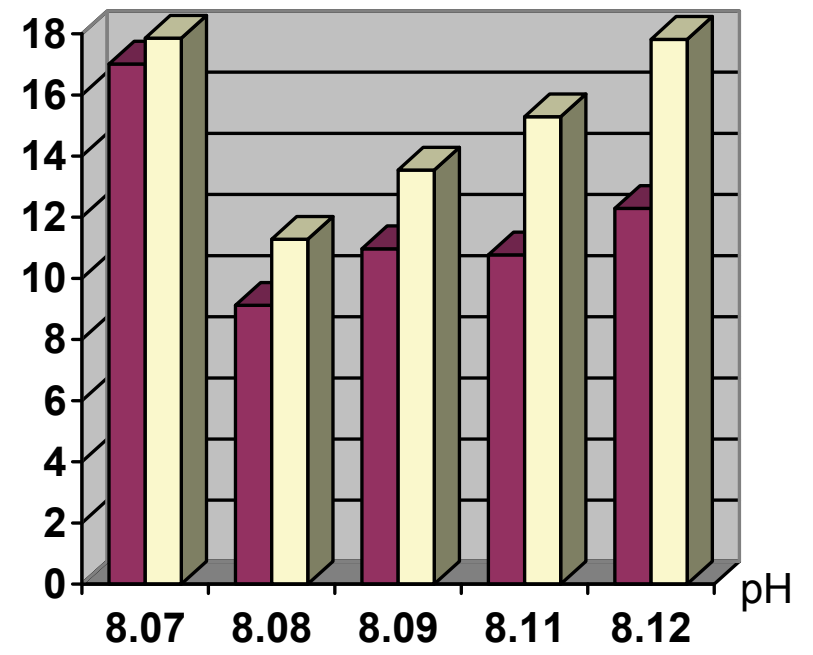

Figure 2. Comparison of final turbidities at initial pH 8 and 100(NTU) turbidity in two stages. Stage1: Ferric Chloride coagulant and Stage2: Ferric Chloride coagulant in accompany with P.ovata coagulant aid.

$$
\text { sludge weight }=0.051 \mathrm{gr} \quad \square \text { sludge weight }=0.050 \mathrm{gr}
$$




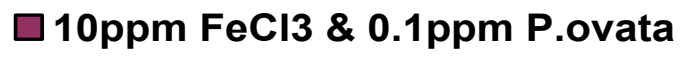 $\square 10 p p m ~ F e C l 3$}

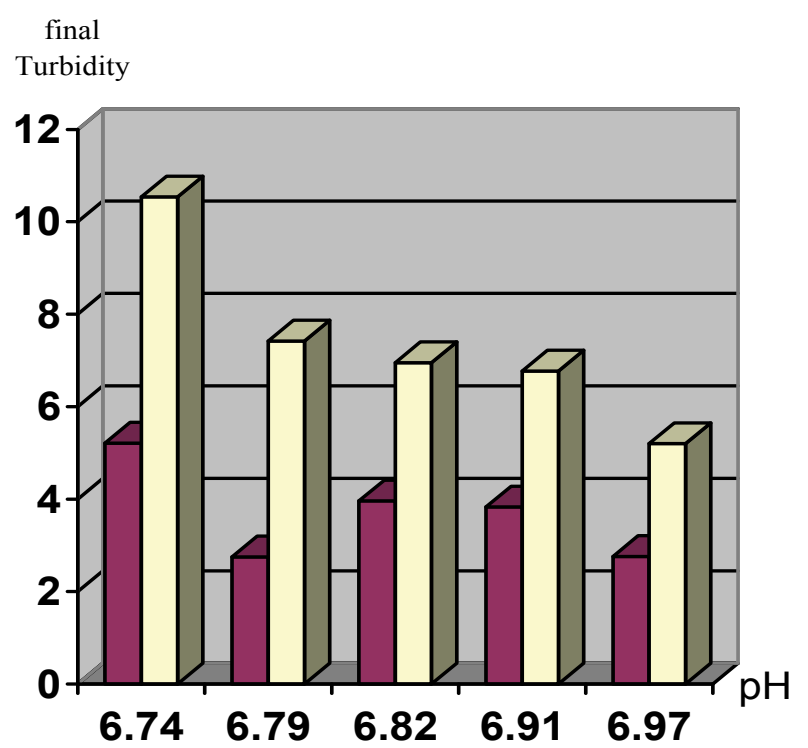

Figure 3. Comparison of final turbidities at initial pH 7 and 50(NTU) turbidity in two stages. Stage1: Ferric Chloride coagulant and Stage2: Ferric Chloride coagulant in accompany with P.ovata coagulant aid.

sludge weight $=0.028 \mathrm{gr} \quad \square$ sludge weight $=0.026 \mathrm{gr}$

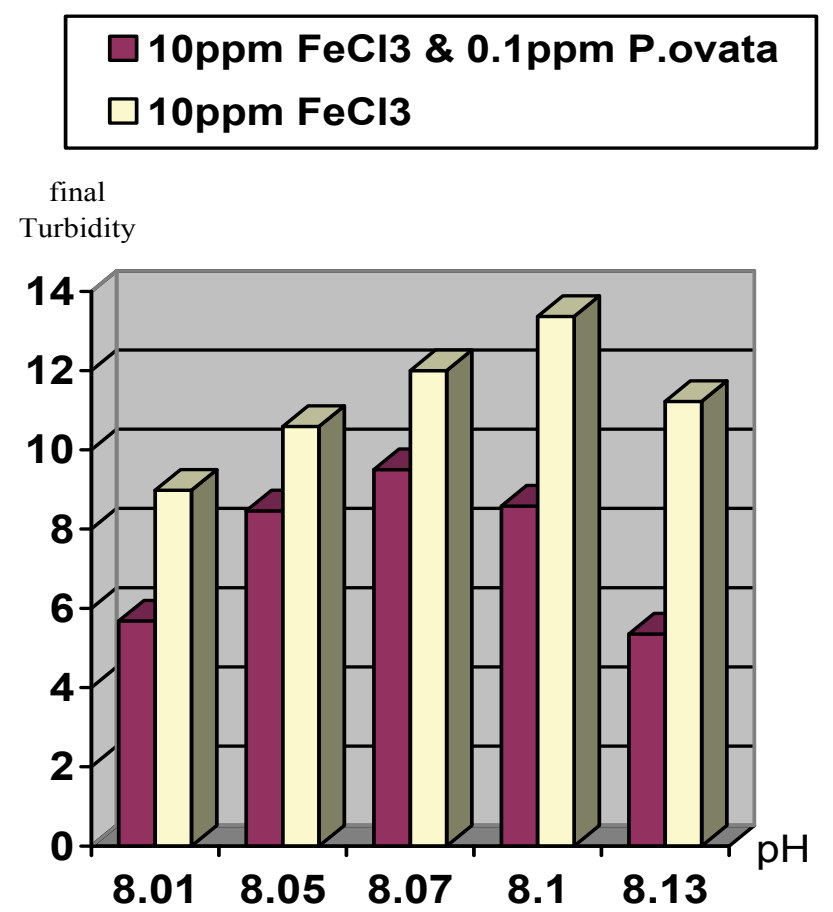

Figure 4. Comparison of final turbidities at initial pH 8 and 50(NTU) turbidity in two stages. Stage1: Ferric Chloride coagulant and Stage2: Ferric Chloride coagulant in accompany with P.ovata coagulant aid.
sludge weight $=0.032$ gr
sludge weight $=0.028 \mathrm{gr}$ 


\section{$\square 10 p p m$ FeCI3 \& 0.04ppm P.ovata \\ $\square 10$ ppm FeCl3}

final

Turbidity

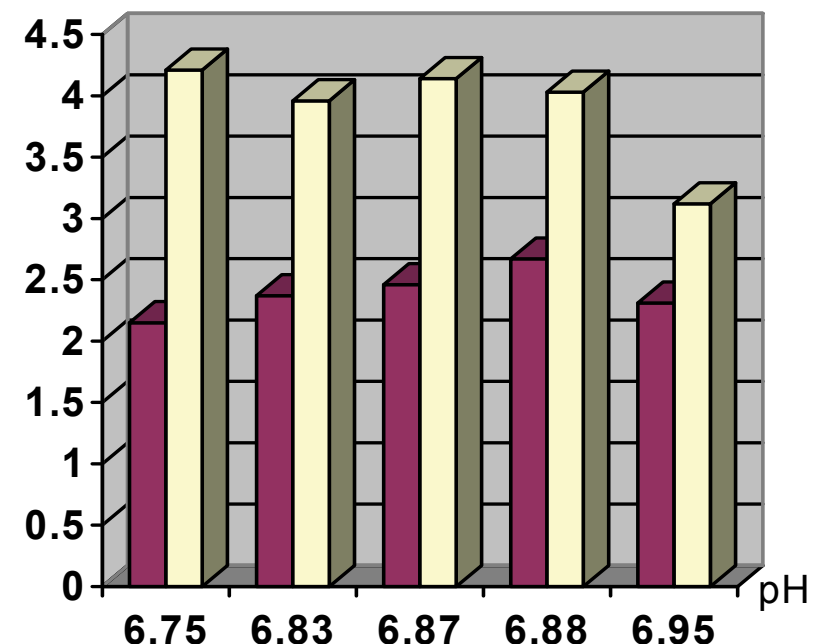

Figure 5. Comparison of final turbidities at initial pH 7 and 20 (NTU) turbidity in two stages. Stage1: Ferric Chloride coagulant and Stage2: Ferric Chloride coagulant in accompany with P.ovata coagulant aid.

$\square$ sludge weight $=0.010 \mathrm{gr} \quad \square$ sludge weight $=0.010 \mathrm{gr}$

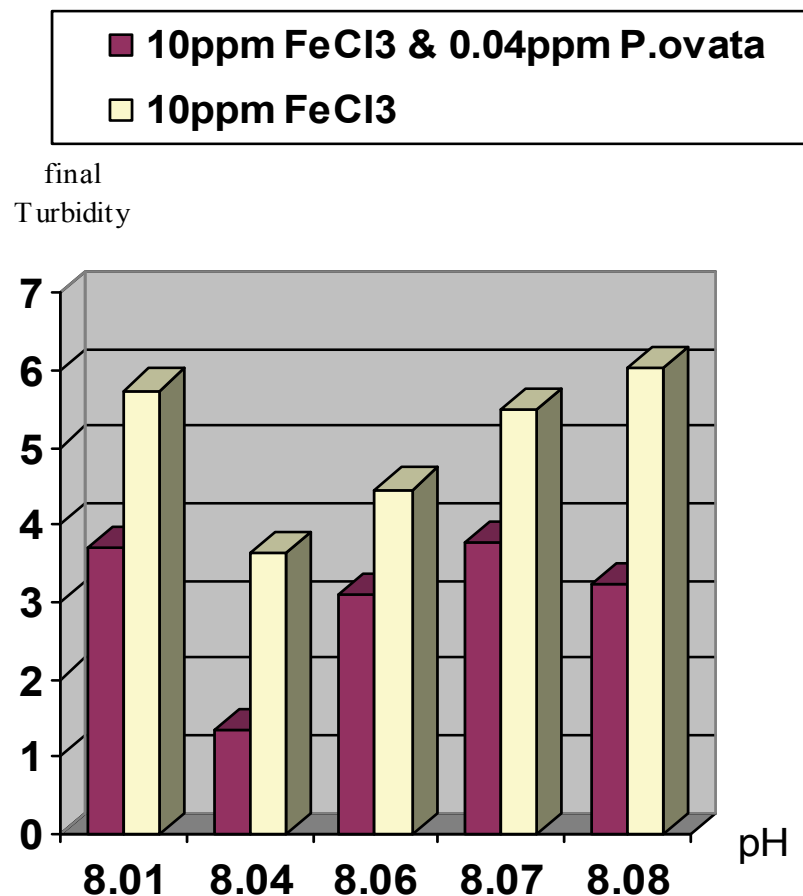

Figure 6. Comparison of final turbidities at initial pH 8 and 20 (NTU) turbidity in two stages. Stage1: Ferric Chloride coagulant and Stage2: Ferric Chloride coagulant in accompany with P.ovata coagulant aid.

sludge weight $=0.012$ gr $\square$ sludge weight $=0.014$ gr 


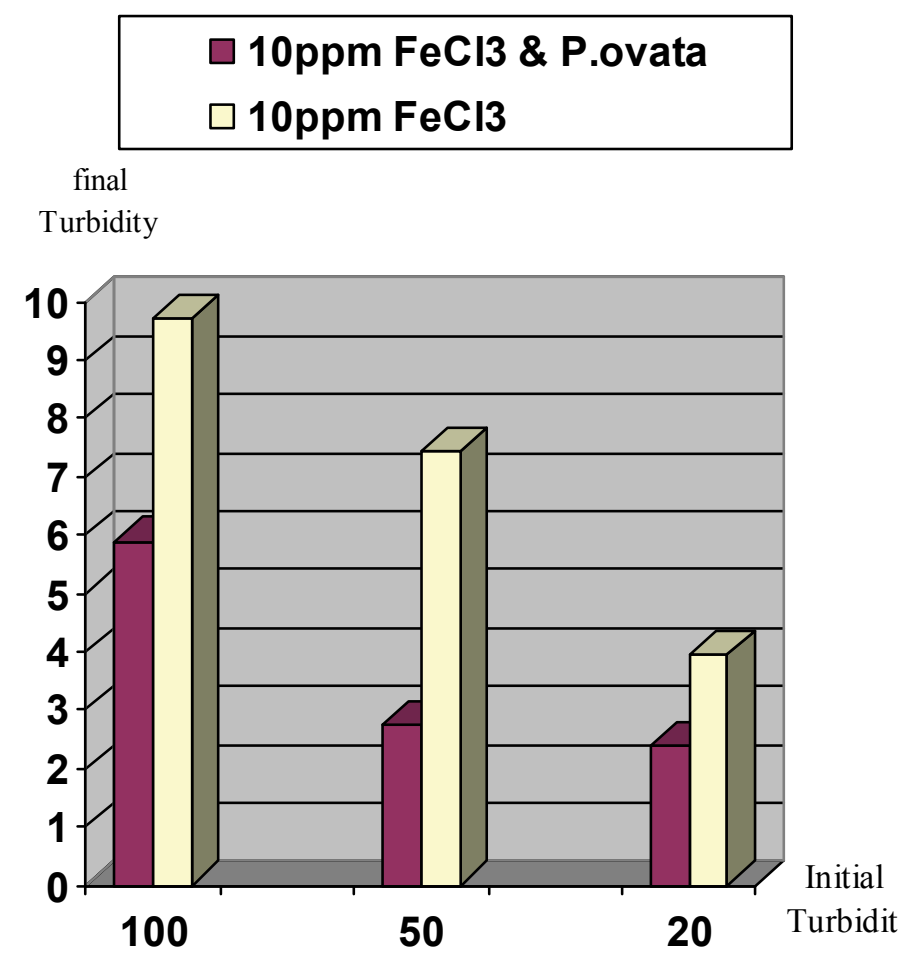

Figure 7. Comparison of final turbidities for the applied turbidities: high, moderate and low in two stages. Stage1: Ferric Chloride coagulant and Stage2: Ferric Chloride coagulant in accompany with P.ovata coagulant aid, pH 7.

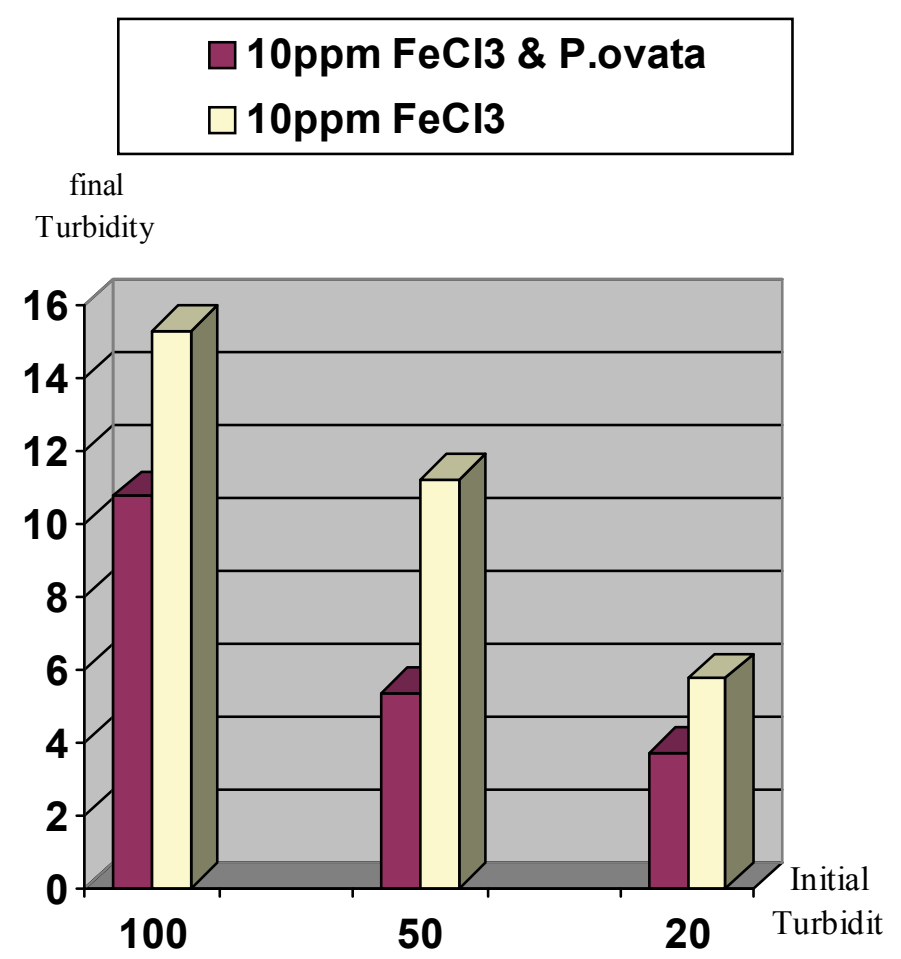

Figure 8. Comparison of final turbidities for the applied turbidities: high, moderate and low in two stages. Stage1: Ferric Chloride coagulant and Stage2: Ferric Chloride coagulant in accompany with P.ovata coagulant aid, pH 8. 


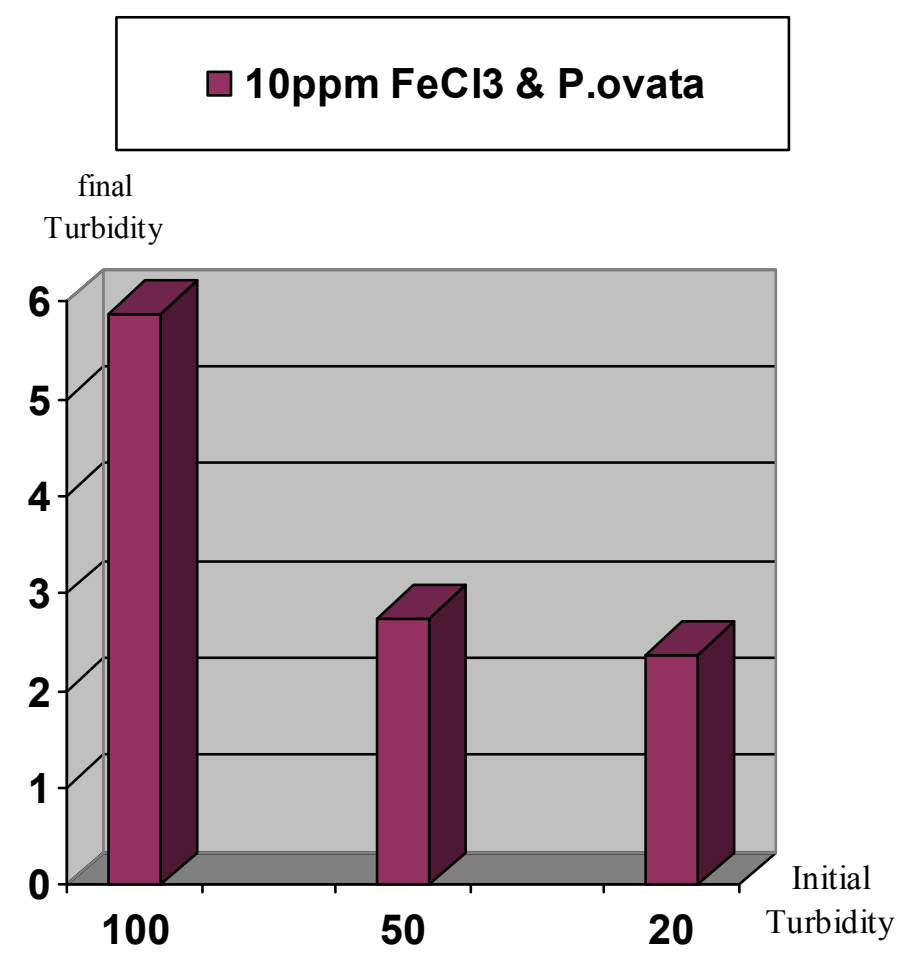

Figure 9. Comparison of final turbidities for the applied turbidities: high, moderate and low in stage: Ferric Chloride coagulant in accompany with P.ovata coagulant aid, pH 7.

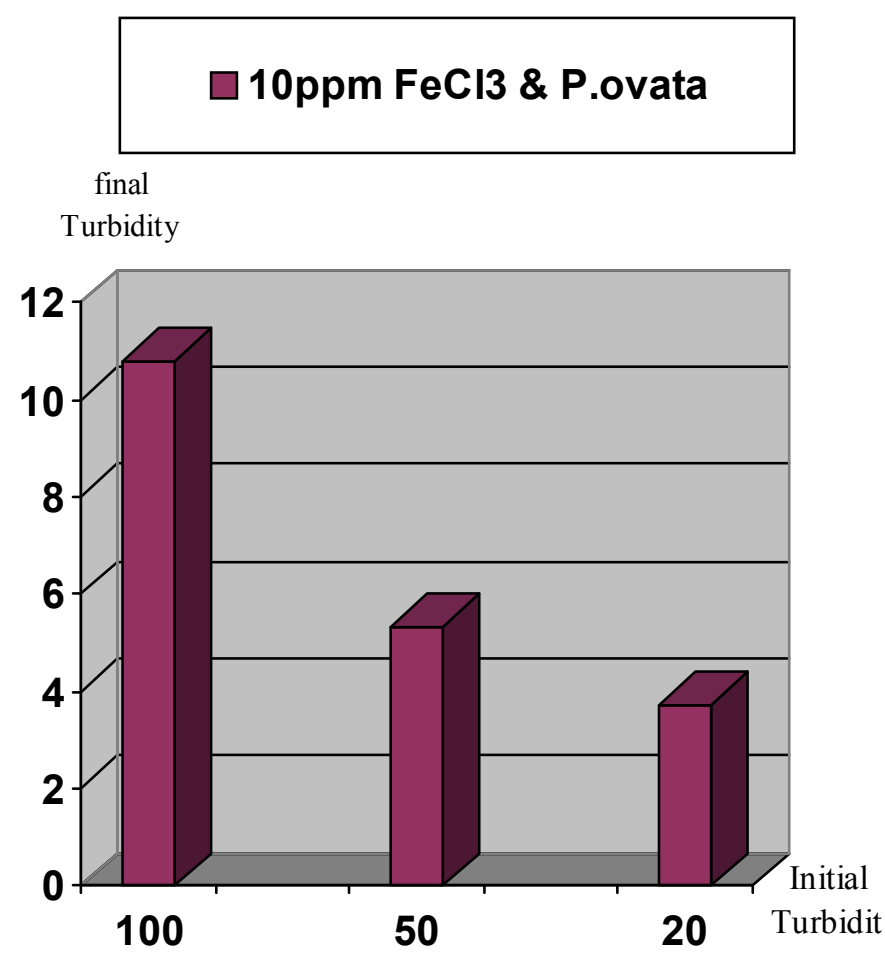

Figure 10. Comparison of final turbidities for the applied turbidities: high, moderate and low in stage: Ferric Chloride coagulant in accompany with P.ovata coagulant aid, $\mathrm{pH} 8$. 
Results indicates that turbidity elimination is ideal in $\mathrm{pH}, 7$ and using Ferric Chloride with P.ovata. Figures 7 to 10 present the comparison of turbidity elimination for all experiments. The results are as follows:

1) Using $10 \mathrm{ppm}$ Ferric Chloride and $0.2 \mathrm{ppm}$ of P.ovata in 100 NTU turbidity and $\mathrm{pH}, 7$ could remove $94.1 \%$ of turbidity, while in $\mathrm{pH}, 8$, turbidity elimination was $89.2 \%$.

2) In moderate turbidity 50 NTU using $10 \mathrm{ppm}$ Ferric Chloride and $0.1 \mathrm{ppm}$ of P.ovata in $\mathrm{pH}, 7$, eliminate $94.5 \%$ of the turbidity while in $\mathrm{pH}, 8$ this value was $89.3 \%$

3) In low turbidity of 20 NTU using $10 \mathrm{ppm}$ Ferric Chloride and $0.04 \mathrm{ppm}$ of P.ovata in $\mathrm{pH}, 7$, turbidity reached to $2.37 \mathrm{NTU}$ and elimination rate efficiency was $88.15 \%$. At the same condition in $\mathrm{pH}, 8$ the removal efficiency was $81.45 \%$.

4) COD measurement results, in all experiment were Nil and it shows that using P.ovata does not have any residual in treated water.

5) TOC in all experiment has been done and there is not any Toc in treated water.

Application of P.ovata plays an important role in turbidity elimination, reducing Ferric Chloride consumption as well as producing sludge significantly.

\subsection{Study the Influence of $\mathrm{pH}$ Variation on P.ovata Performance}

In this section of research, jar test on water sample with $\mathrm{pH}, 7$ was repeated and in each time of injection specified quantity of P.ovata has used as coagulant aid. The results of these tests are presented in Figures 1, 3, 5, 7 and 9 .

The influence of P.ovata on coagulation process increases with P.ovata injection enhancement. However, if P.ovata injection exceeds its optimum value, its effect will decrease. Increase in the efficiency of water turbidity removal was observed in low $\mathrm{pH}$ values, should be determined under conditions in water treatment plants.

\subsection{The Influence of P.ovata Utilization on Sludge Production}

The produced sludge from water plant operation is classified as chemical sludge which should be disposed under specific procedures in some countries. Sludge production reduction is the first step to decrease investment cost and sludge transfer and removal operation. One technique is simultaneous utilizations of Ferric Chloride and coagulant aid. When P.ovata is selected as a coagulant aid, consumption of Ferric Chloride decreases that leads to decrease of sludge production.

\subsection{Economic Explanation of P.ovata Application in Water Treatment}

In this research economized value of variation of consumption of chemical materials was studied. If consumption of P.ovata leads to decrease in Ferric Chloride consumption, with considering global and regional price of this material, it is possible to estimate decreased cost of chemical materials.

Totally, the following results were obtained from the tests:

1) The efficiency of P.ovata seed extract coagulant aid is influenced by $\mathrm{pH}$ and optimum $\mathrm{pH}$ increases its efficiency.

2) In turbidity of $50 \mathrm{NTU}$ the seed extract of P.ovata in concentration of $0.1 \mathrm{ppm}$ with $10 \mathrm{ppm}$ of Ferric Chloride can eliminate turbidity more than Ferric Chloride in concentration of alone.

3) With turbidity reduction to $20 \mathrm{NTU}$, efficiency of P.ovata decreases, however leads to standard turbidity level.

4) According to the results presented in figures and tables of this research, the extract of P.ovata does not reduce final $\mathrm{pH}$ of water sample, while using Ferric Chloride alone reduces final $\mathrm{pH}$ of the samples.

5) $\mathrm{pH}$ reduction improves the performance of Ferric Chloride alone as well as Ferric Chloride in accompany with P.ovata.

6) Using coagulant aid promotes the efficiency of Ferric Chloride and reduces the turbidity more than alone situation.

7) The seeds of this plant are much cheaper than artificial coagulant aids. This plant is sowed in Iran and readily accessible. In addition, from health aspect, not only P.ovata does not have any harmful effect in comparison with artificial coagulant aid but also it used as a medicinal plant. Finally it is recommended that the same research is conducted on the influent of water treatment plants in pilot scale.

\section{References}

[1] A. G. Kebreab, "Moringa seed and pumice as alternative natural materials for drinking water treatment," KTH Land and Water Resources Engineering University, TRITA, LWR PhD THESIS 1013, 2004.

[2] R. Menahem and M. Lurie, "Control of organic matter by coagulation and flocculation separation," Water Science and Technology, Vol. 27 , No. 11, 1993.

[3] Water industry standards, "Drinking water quality standard," Vol. 6, July 1987.

[4] M. C. Amiri, "Water treatment principles," Arkan Publication, Isfahan, 2006.

[5] HDR Engineering, Inc., "Handbook of public water systems," John Wiley and Sons, Inc., New York, 1991. 
[6] A. A. Shahmansuri and A. A. Neshat, "Comparison among Poly Aluminium Chloride, Aluminium Sulphate and Ferric Chloride in TOC and total Coliform removal," Water and Waste Water Journal, Vol. 48, pp. 39-44, 2003.

[7] A. A. Tatsi, A. I. Zouboulis, K. A. Matis, and P. Samara, "Coagulation-flocculation pretreatment of sanitary landfill leachates," Chemosphere, Vol. 53, pp. 737-744, 2003.

[8] D. Wang, W. Sun, Y. Xu, H. Tang, and J. Gregory, "Special stability of inorganic polymer flocculant-PACI," Colloids and Surfaces, Vol. 243, pp. 1-10, 2004.

[9] D. R. Parker and P. M. Bersch, "Formation of the ' $\mathrm{Al}_{13}$ ', tridecameric polycation under diverse synthesis conditions," Environment Science Technology, Vol. 26, pp. 914-921, 1992.

[10] V. K. Lamer and T. W. Healy, "Adsorption-flocculation reactions of micro molecules at the solid-liquid inter face," Review of Pure and Applied Chemistry, Vol. 13, pp. 112-132, 1963.

[11] S. Naseri, "Coagulation and coagulants process: Total principles and practical methods in water treatment industry," Congress Articles Collection of Coagulants in Water Industry, Ahwaz, November 1996.

[12] S. Kawamura, "Effectiveness of natural polyelectrolytes in water treatment," AWWA, Vol. 83, No. 10, pp. 88, October 1991.

[13] R. Christopher, S. Daniel, and A. Okun, "Surface water treatment for communities in developing countries," ITDG Publishing, pp. 300, 1992.

[14] A. Diaz, N. Rincon, A. Escorichvela, and N. Fernandez, "A preliminary evaluation of turbidity removal by natural coagulants indigenous to Venezuela," Process Biochemistry, Vol. 35, pp. 391-395, 1999.

[15] R. D. Letterman and R. W. Pero, "Contaminant in polyelectrolytes used in water treatment," AWWA, November, 1990.

[16] S. Kawamura, "Effectiveness of Chitosan for water treatment," Penerbit University Kebangsaan Malaysia, Bang, 1995.

[17] K. L. Chadho and G. Rajender, "Advances in horticulture medicinal and Aromatic plants," Vol. 11, Maldorta. Pub., New Delh, 1995.

[18] B. D. Basudehradun, S. Bisha, and S. Manhendrapol, "Indian medicinal plants," Today and Tomorrow's Publishing, Vol. 1-5. pp. 1-1033, 1989.

[19] A. Zargari, "Medicinal plants," Published by University of Tehran, Vol. 4, 1997.

[20] F. A. Ghahraman, "Flour of Iran," Published by Institute of Jungles and Grasslands Research, Vol. 1-18, 1982 1996.

[21] S. P. Raychaudhuri and J. Ahmad, "Cultivation of important medicinal plants in India," In Glimpses in Plant Research, Today and Tomorrow's Printers and Publishers, New Delhi, Vol. 10. pp. 247-256, 1993.

[22] L. Hornock, "Cultivation and processing of medicinal plants," Academic Publishing Budapest, 1992.

[23] Y. Ayinehchi, "Simple substances in medicine and Iran medicinal plants," Published by University of Tehran, 1986.

[24] N. Kumar, J. B. M. Abdulghader, P. Rangaswami, and I. Irulappen, "Introduction to spices, plantation crops, medicinal and aromatic plants," Oxford and IBH, 1997. 